\title{
The Role of "Jigsaw" Method in Enhancing Indonesian Prospective Teachers' Pedagogical Knowledge and Communication Skill
}

\section{Leli Halimah}

Universitas Pendidikan Indonesia, Indonesia, lelihalimah@upi.edu

Vidi Sukmayadi

Universitas Pendidikan Indonesia, Indonesia, vsukmayadi@upi.edu

The broad context of this paper is based on the authors' fieldwork experience in implementing a jigsaw-type cooperative learning method. The paper aims to explore the role of Jigsaw Model for prospective teachers' understanding of pedagogical content knowledge and how it can be integrated with their instructional communication skill. This study was a qualitative case study. Sixty second-year university students were involved as the study participants. Data were gathered through observations, field notes, and interviews with key respondents. The data were thematically analyzed, and they were interpreted based on the prepared achievements indicator. The results of the study reveal that the implementation of a jigsaw-type cooperative learning method is successful in improving both pedagogical content knowledge and verbal communication skill of the prospective teachers.

Keywords: Jigsaw type, cooperative learning, instructional communication skill, learning method, pedagogical skill

\section{INTRODUCTION}

The 21st-century teacher education programs are developed to produce highly qualified teachers (Cohan, A., \& Honigsfeld, 2011; Gore, Griffiths, \& Ladwig, 2004; Rots, Aelterman, Devos, \& Vlerick, 2010). The primary goal of teacher education for all levels of education is educating and producing excellent teachers for the future (Gore et al., 2004). Well-Qualified teachers are needed because their performance is always attributed to their students' academic achievements (Cohan \& Honigsfeld, 2011). However, not all teacher education programs resulted in producing good teachers, much criticism of teacher education quality is directed at how teachers were educated and prepared back at their institution.

Citation: Halimah, L., \& Sukmayadi, V. (2019). The Role of "Jigsaw" Method in Enhancing Indonesian Prospective Teachers' Pedagogical Knowledge and Communication Skill. International Journal of Instruction, 12(2), 289-304. https://doi.org/10.29333/iji.2019.12219a 
The criticism implies that an institution of teacher education has the responsibility to train prospective teachers that meet the education market needs (Gore et al., 2004). A teacher education institution should actively support the prospective teachers in mastering the knowledge, skills, and characters within the professional teaching and learning process (Cohan \& Honigsfeld, 2011). However, one of the teacher requirements of a qualified teacher is the one who can communicate the messages effectively within their subject matters.

Teacher education programs should be able to train prospective teachers to have both the pedagogical skills and the communication skills toward their students (Frymier \& Houser, 2000; Ngang, Hashim, \& Yunus, 2015). Moreover, a professional teacher is compelled to have a competent and pleasant communication style (Ramdhani, Ancok, Swasono, \& Suryanto, 2012). Teachers' ability to communicate well is as important as mastering the pedagogical content knowledge. In line with this, Russo et al. (2013) stated that a teacher should be competent in communicating with students and a teacher should be able to become a good role model for the students regarding how a teacher should communicate.

Previous empirical studies have shown that teachers with excellent verbal communication skills were positively related to students' high academic achievements. One of the critical findings reveals that students who are taught by teachers with excellent verbal communication skills have better academic performance than those taught by teachers with lower verbal communication skills (Ozkan, Dalli, Bingol, Metin, \& Yarali, 2014). The cause of this lies in the fact that teachers who have excellent verbal skills can convey ideas to their students more efficiently (Khan, Khan, Zia-UlIslam, \& Khan, 2017). In this case, teachers have a more challenging responsibility because they have to both communicate the learning content and deliver the best delivery method in front of 20 - 30 students at a time, each with unique needs and characters (Bullock, 2011).

It is essential that teachers should have excellent communication competence. For that reason, the current study aims at investigating the role of Jigsaw model for the prospective Indonesian teachers in understanding pedagogical content knowledge and exploring how the cooperative learning method can develop the prospective teachers' verbal communication competence.

\section{LITERATURE REVIEW}

\section{Teachers Education Program and Communication Skills}

A pre-service teachers education program should be able to produce teachers with a decent competency of pedagogic, personality, and social responsibility (Departemen Pendidikan dan Kebudayaan, 2005; Ramdhani et al., 2012). Within each competency, whether it is stated explicitly or not, there is a demand for teachers to have sufficient communication skills.

Within the teachers' education program, prospective teachers ought to understand the pedagogic knowledge and literacy to support their teaching and learning process 
(Kukner \& Orr, 2015). Field practice is one compelling content area included in the teacher's education program. By having field experiences the students should be allowed to experiment with new ideas, even if they might make mistakes, they are given chances to solve problems (Ibrahim, 2013). Pre-service Teachers Education program should be able to support the students by adjusting the teaching and learning strategy that suitable with today's needs (Wiens, Hessberg, LoCasale-Crouch, \& DeCoster, 2013).

Teachers Education Program should provide teachers with materials and skills during the teachers' preparation and before their first step of teaching. Providing teachers with such services will affect their long-term career (Sutiyatno, 2018). It will be even better if, during the pre-service teacher's program, they can get a role model in providing them with real experience and their needs in the classroom.

The definition of communication is a form of information exchange through interaction among people. Communication is a process that includes creating and exchanging messages with other people (Fujishin, 2009; Koprovwsa, 2014; Moore-Russo et al., 2013). There are two ways of communication, verbal and non-verbal (Sutiyatno, 2018). Both of the ways work together at the same time during the process of delivering and receiving messages. Verbal communication covers spoken and written communication while non-verbal communication covers appearance, tone, facial expression, gestures, and other paralinguistic features.

Communication is also known as a form of art. Communication skills can be enhanced through practices, like practicing the use of non-verbal signs (gestures, facial expression, and body posture) during the communication process. Non-verbal communication is as significant as the verbal communication itself. It means that when someone is speaking, other people can "read" the non-verbal signs delivered by the speaker (Grace \& Gilsdorf, 2004).

Related to the teacher and student relations in the classroom, both should have a reciprocal role as the agent and receiver of information, just like the way communication works in real life (Soares, 2015). In their teaching, teachers generally deliver a message to their students. The message is delivered to inform, affect, or change students' attitude and opinion towards their behavior. Verbal communication that takes place between teachers and students is a complicated process as there is more than one participant who acts as the receiver. Hence, it is necessary for teachers to be an effective communicator in delivering their information. As communicators, they should be able to express themselves well. A suitable communication competence includes appearance, eye contact, speech rate, volume, vocal tone, facial expression, posture, body gesture, and hand movement. All these elements will create an overall impression from one communicant to another about "who" you are, not "what" you say (Fujishin, 2009). One of the prominent keys in good communication is an understanding of the message that is being delivered and the use of precise words; incorrect words might lead to a misunderstanding (Russo et al. 2013).

Communication skills seem simple in theories, yet to achieve a decent level of communication skill, constant practice and reflection are a must. There are many ways 
to practice our communication skills, one of them can be done in a group activity. To put it simply, communication skills are just like any other skills, to acquire the skills we need to drill ourselves into practice (Khan et al., 2017). Verbal communication skills might be enhanced through classroom presentation, starting with an easier task and moving to a more challenging assignment (Grace \& Gilsdorf, 2004).

The teaching and learning environment created in a classroom is mainly categorized as part of the communication process between teachers and learners. In an educational context, there are so much information that a teacher should Get across to his/her learners in an attempt to fulfill teachers' professional task in a classroom. For instance, a teacher needs to communicate what objectives the learners have to achieve, what materials they are going to learn and what assignments they are required to do.

\section{Jigsaw Model as a Form of Cooperative Learning}

Cooperative learning is a learning method that requires learners to work together in small groups (Gillies, Ashman, \& Terwel, 2008). It means that the students learn the subject along with their peers, sharing information and giving arguments based on their understanding of the content to find one conclusion. This method allows learners to share responsibilities to achieve good results in learning and have an opportunity to learn to respect each other so that the group's harmony can be maintained (Soares, 2015).

The essence of cooperative learning requires pupils to work together in small groups to support each other and to improve their learning and that of others (Jolliffe, 2012). In line with this statement, Kagan (2009) argued that working cooperatively in teams is a terrific experience for students and provides opportunities for them to develop their social and life skills that will serve them well throughout life.

There are many models of cooperative learning that teachers can implement, including jigsaw model. One characteristic of the jigsaw model is the existence of the original group and "expert" group (Benton, 2016; Kagan \& Kagan, 2009). There are five essential factors in the implementation of the jigsaw model of cooperative learning. Those factors are: positive interdependence, positive face-to-face interaction, individual accountability, interpersonal and small-group skills and learning reflection (Gillies et al., 2008; Syarifuddin, 2011). Furthermore, the two most essential elements are positive interdependence - 'We sink or swim together' and individual accountability - 'No Hitchhiking!' (Jolliffe, 2007).

The Jigsaw Strategy is one of the efficient ways to learn the course material in a cooperative learning style. The jigsaw process encourages the skills of listening, social engagement, and empathy by giving each member of the group a prominent part to engage in an academic activity (Azmin, 2015). Students must work together as a team to achieve a common goal; each person depends on all the others. No students can succeed unless everyone cooperates well together as a team. This "cooperation by design" encourages interaction among all students in the classroom, leading them to appreciate each other as contributors to their shared task (Aronson \& Bridgeman, 1979). 
Since the 1980s, the study of Jigsaw Classroom strategy to enhance autonomy-oriented learning process has been carried out (Carroll, 1986; Deci, J. Schwartz, Sheinman, \& Ryan, 1981; Slavin, 1980) and comprises many related studies to this date. Other previous studies in the 2000s focused on the Jigsaw strategy and its effect to the students psychological aspects. Most of the research used structured surveys of human respondents (Aronson, 2002; Dalgleish et al., 2007; Eilks, 2005; Syarifuddin, 2011) and, more recently, the studies were focused on the teachers' teaching variations by using jigsaw strategy and how the students gained practical benefits from it from the students' personal perspectives (Aydin \& Biyikli, 2017; Azmin, 2015; Benton, 2016; Cardozo, Miranda, Moura, \& Marcondes, 2016). Much fewer of the previous studies have addressed the teachers' communicative skills as an outcome of the jigsaw teaching strategy. Thus, this study focuses on analyzing and identifying the roles of the jigsaw type of cooperative learning in supporting the prospective teachers' understanding toward the pedagogical content knowledge and developing their verbal communication competence.

The Jigsaw instructional method is a highly structured cooperative learning technique swhich was created by Aronson (Aronson, 2002; Syarifuddin, 2011). In the implementation of the Jigsaw Method, the teacher introduces a topic and its subtopics. The students are then divided into 'original' groups, where they are each given a different subtopic in the group. The next phase requires the students to break out of their 'original' groups to form the 'expert' groups where these students focus on one subtopic, investigating, analyzing, and discussing it. Thus, the students become experts on the assigned subtopic. After finishing their discussion, the students from all of the 'expert' groups must return to the 'home' groups and share the information with their peers based on their findings and discussions (Azmin, 2015). After some time, all the members of the 'home' groups will have learned from each expert group discussion and will have benefitted from each other.

Furthermore, the Jigsaw method is a grouping strategy in which the members of the class are organized into "original" groups. The students in the classroom are then reorganized into "expert" groups containing one member from each original group. The members of the expert group work together to learn the material or solve the problem that they received from their instructors, then return to their original groups to share their findings. In this way, the findings and understandings of the expert groups are speedily disseminated throughout the class, with each student taking responsibility for sharing a piece of the puzzle.

As a whole, jigsaw puzzle as a cooperative learning method is beneficial for learners in terms of encouraging learners to participate, both academically and cognitively, and thus to develop their social skills such as communication, presentation, problem-solving, and leadership (Gillies et al., 2008; Kouwenhoven, Ernestus, \& van Mulken, 2016). Jigsawtype cooperative learning method can be proposed as one of the teaching methods taught to pre-service teachers to be implemented later in their classrooms. 


\section{METHOD}

\section{Research Design}

This study employs a descriptive qualitative approach by conducting a case study. There are fourteen meetings arranged in one semester, 100 minutes ( 2 credits semester) for each session. The data are collected based on the characteristics of descriptive qualitative research, through observation, field notes, and interviews (Creswell, 2013). Constant observations were conducted to observe the performance of pre-service teachers in utilizing their communication skills. Students' activity indicators were made in the observation checklist. Field notes were also taken to describe which barometers are suitable for the standard. Interviews were also administered to pre-service teachers to investigate their self-confidence when they have to speak in front of their classmates. At the end of the implementation, a reflection session was scheduled to evaluate and share the participants' feedback on the outcome of the planned activity by looking at the benefits and possible challenges.

The study is shaped by the following research questions to guide the authors in collecting and analyzing the data. The questions are (1) What roles can the Jigsaw model have for enhancing the prospective teachers' pedagogical knowledge? (2) In what ways can the Jigsaw Model increase the prospective teachers' verbal communication skills?

\section{Research Site and Participants}

The study was conducted at the Department of Early Childhood Education, Universitas Pendidikan Indonesia (Indonesia University of Education). All of the participants were in their fourth year. The participants were pre-service teachers who studied at the department in the same university. There are 60 participants divided into two classes (A and B); each consists of 30 participants. For the study purpose, all of the participants' anonymity and confidentiality were guaranteed.

\section{Data Analysis}

The primary data is collected by applying class observations. The observations were conducted systematically and continuously from one time to another during the communication activities performed by participants in groups. In this study, the observation was conducted during 2017/2018 even semester. The authors also used field notes and interview transcript in analyzing the data (McMillan \& Schumacher, 2001). Each set of data collected were continuously analyzed and interpreted as the basis for the conclusion.

The communication skill developed during the implementation of cooperative learning jigsaw model emphasizes an interactional communication type, which involves speaker and listener. The speaker acts as an information source who delivers a message to the listener while the listener plays the role of a responder. The speaker might want to adjust the way they communicate to reach a mutual understanding (Effendi \& Sukmayadi, 2016; Fujishin, 2009). 
Observations were conducted continuously using a checklist guideline when participants shifted role to be the information sources to identify their verbal communication skill development. Following the observations, a focus group discussion was conducted to confirm the findings and to receive feedback on the learning process and the participants' verbal communication skills. The discussion was focused on the participants' expression skills, language communicativeness, understanding of the assigned topics, and presentation techniques during their jigsaw puzzle activities.

\section{FINDINGS}

\section{Implementation of Jigsaw-type Cooperative Learning Model}

As mentioned before, the study was conducted at the Department of Early Childhood Education, Universitas Pendidikan Indonesia. Initially, the department implements learning and curriculum as one of the subject courses. It contains materials about the concepts, development, elements, principles, approaches, and innovations in learning and curriculum development. These primary materials are provided for pre-service teachers about the progress of their pedagogics knowledge. It is necessarily essential for them to master the pedagogical content.

Professional teachers are required to learn; they learn how to study, and transform their knowledge into practice for the sake of their students' development in future time (Avalos, 2013). In teachers' education program, it is necessary to provide a meaningful learning experience and a supportive learning environment (Gore et al., 2004).

The Jigsaw method was chosen as a method to be learned by the department prospective teachers. The jigsaw method is a technique of organizing classroom activity that makes learners dependent on each other to succeed. The class is divided into groups and breaks assignments into pieces that the group assembles to finalize the "jigsaw puzzle" (Kagan \& Kagan, 2009).

The implementation of jigsaw-type cooperative learning can serve as a method to help prospective teachers to master the pedagogical content and at the same time to enhance in their verbal communication skills. The jigsaw learning model is aimed to promote better learning, improves student motivation, and increases enjoyment of the learning experience

The authors conducted the learning process by referring to the jigsaw cooperative learning method (Aronson \& Bridgeman, 1979; Kagan \& Kagan, 2009). The implementation of the activities is as follows:

\section{Preliminary Activities}

a. Both students and their lecturer discussed their expectation to become a professional teacher.

b. The students paid attention to the course objectives according to the syllabus; 
c. The teacher motivated the students to prepare themselves to be well qualified prospective teachers and fulfill the national education standards for teachers' qualification.

d. Both of the Students and the lecturer committed to improving the course comprehension by agreeing to have an open and intensive communication;

e. Group forming: Original Group and "expert" group

- Activities on the Original Group:

1) Students were asked to make six groups; each group consists of five students. Each group is labeled by alphabet letters (A, B, C, D, E, and F), each group member is given numbers one to five.

2) Each group received different subject matters related to that day topic.

3) Each group divides the topics to be discussed by group member based on their number.

\section{Core Activities}

a. Activities on the "expert" group

1) Each student from the original groups was asked to fall out and make an "expert" group that consists of students with the same number and the same topic.

2) Inside the "expert" group, they were sitting in a circular setting. The students jointly studied the topic using various sources, such as books, journals, and the internet for more in-depth comprehension. Subsequently, the students made the resume in forms of description, small notes, and concept maps so that they could re-convey the results of the in-depth discussion back to the original group.

3) Each member of the "expert" group should relay his or her findings back to the original group. In other words, the students from the "expert" group were given a sufficient opportunity to deepen their understanding and to present the findings in front of their friend when they were back in the original group.

4) After the students went back to their original group, the students were asked to take turns in presenting their findings, and they were expected to deliver the results communicatively (not allowed to read from the notes, students had to maintain eye contact with the audience, be confident and speak communicatively).

5) Peer evaluation: Each member gav feedbacks regarding the presented findings.

b. Activities in the Original Group:

1) The Members of the "expert" group, re-gathered back to their original group to present their discussion results.

2) Presentation: Every member of the group presented their finding in numerical order based on their assigned topic. 
3) Presentation requirements: The Listeners (original group members): had to pay attention; listen carefully; appreciate the speaker, and had to make notes on things that are considered significant. On the other part, The speakers ("expert" group members): when they did the presentation, they learned to be confident, learn to maintain their eye contact, not reading their notes, and to be more expressive in presenting the topic. (Each listener used an observation sheet to help them in providing inputs to their friends who were doing the presentation).

4) A class discussion was conducted after all speakers had presented the assigned topic in each original group. This step was performed as an elaboration of various findings from the discussion results that they have discussed in both original and "expert" groups

5) After the class discussion, the lecturer provided comments that led to an explanation for a more comprehensive understanding of the concepts as well as commented on the students' communication skills during their in-group presentations.

3. Closing Activities:

1) One representative from each "expert" group presented the summary from the overall lesson of that day.

2) The lecturer then provided the students with some additional explanations for the enrichment of pedagogical content knowledge and opened class discussions according to the cases raised by each representative.

3) The next activity was a quiz session to see whether the students understand the content material. A 10-question quiz was given. The students directly corrected the results of the exam by swapping the answer sheet so that both the students and the lecturer can know the outcome.

4) Afterward, the lecturer led the reflection session on the results of the quiz and the development of students 'verbal communication skills and provided inputs to the students' performance.

5) Finally, the lecturer made notes of the quiz results and the development of the students' verbal communication skills (presentation) for further perusal.

In the grouping setup, each student is assigned to an expert group and an original group, thereby having a dual designation. The illustration of the grouping setup can be seen in the following diagram: 


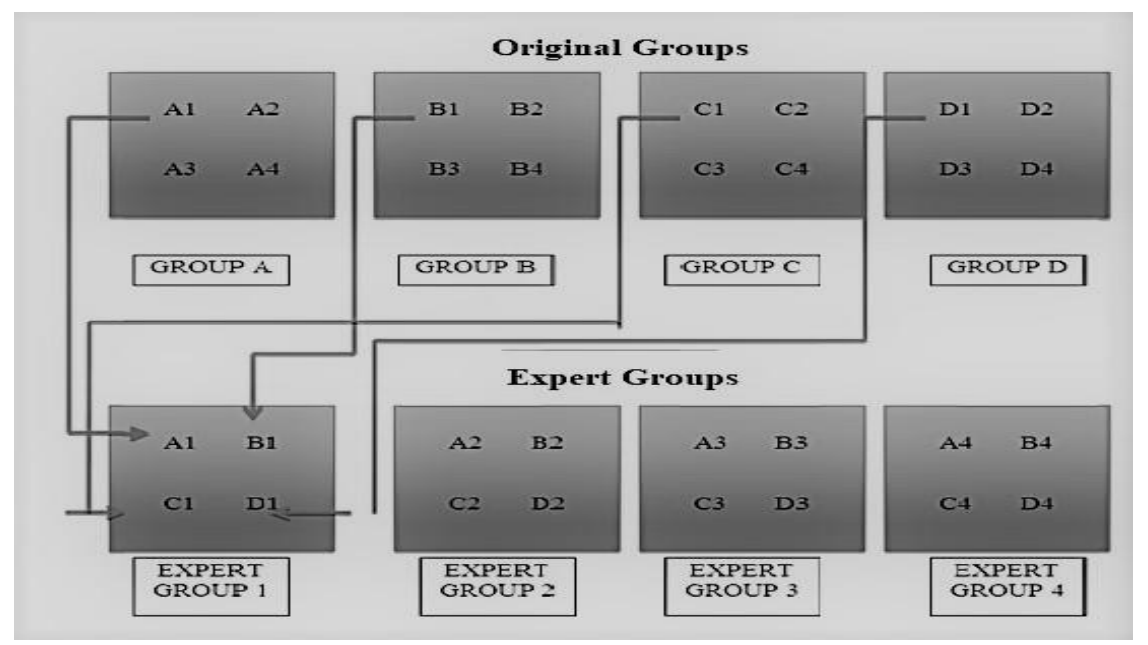

Figure 1

The setup of the students' grouping where the jigsaw technique is applied

\section{The Roles of the Jigsaw Method in Prospective Teachers Pedagogical Knowledge}

The observation findings indicate that the Jigsaw model was able to assist both students from class A and B to a better understanding of the pedagogical content or the topic of the discussion. The authors employed observation notes to monitor their understanding of the content while discussing in each subgroup. The overall observation indicators in communication skills include Expression skills; Language quality; Understanding of content; Fluency; Presentation. Based on the observations, in the reading groups, students within a group had the same primary article. In discussion groups, all articles are equally represented. As a result, the students had more opportunity to speak up in each subgroup because they only focus on only one particular subtopic (Observation, March 15, 2018)

The application of the jigsaw type cooperative method in the Curriculum and Learning class was able to create an enjoyable atmosphere, and the activities were able to increase the prospective teachers' motivation during the lecture. Their enthusiasm could be seen during their discussion in the "expert" group and when they returned to the original group to present their findings. Based on the class observation, most of the students looked for the needed information by using their smartphones, tablets, laptops, and relevant books. They were very eager to get comprehensive and detailed information (Observation, March 22, 2018).

By the time the students returned to the original group to present their findings, the lecturer had reminded them of the communicative requirements. They had to improve their presentation skills by considering the audience's characters, what messages the speakers wanted to convey, which channels were available and how to deliver the message, all of which must be prepared as best as possible (Benton, 2016). In this case, after the students return from the so-called "expert group" they can speak up their 
understanding in the original group (Observation, March 22, 2018). Furthermore, this method was implemented repetitively for the rest of the semester. At the final class debriefing on the semester, the students admitted that they gained valuable experience in peer-discussion based activities. They could understand the subject matters at a more profound and broader level (Class debriefing, June 7, 2018).

In connection to the prospective teacher students' reactions, the Jigsaw-type cooperative Learning Method is fundamentally acknowledged as a pedagogical practice that promotes metacognition, prosocial behavior, and more significant understanding because of its diverse learning, and the individual's need for socializing (Gillies et al., 2008; Syarifuddin, 2011). Also, the jigsaw model gives another advantage in the form of fostering the students' social skills development such as communication, presentation, problem-solving, leadership. Thus, not only can the students understand the course materials very well, but also, they will be able to develop their verbal and instructional communication skills (Gillies et al., 2008; Koprovwsa, 2014).

\section{The Jigsaw Method and Students' Communication Skills}

An increased understanding of pedagogical content knowledge helped the students in increasing their communication confidence. To improve the communication skills of the prospective teachers, they have to present their finding in small groups both in the "expert" group and in the original group; gradually there is an effort to not depend on the written notes. Having notes results in the unavailability of a relaxed communication between the members of the group (Observation, 29 March 2018). In the 4th to the 6th meeting, the students were asked to make only small notes. The notes can be used whenever they forget what they should say during the presentation. This conditioning can help the students establish a communicative interaction with the members of their group. For the next attempt, to further improve the communication skills, the students were asked to make a map of concepts related to the relevant matters that they deliver. The use of mind mapping was conducted during the next three meetings (the 7 th to the 9th meeting). This method helped the students to be more confident during the presentation, and spoke communicatively. The next step was to ask the students to prepare themselves, that is, to understand thoroughly the material that will be presented, while at the presentation they focus on creating a communicative interaction with the members of the group, with the direction of maximal actualization (contacts of view, expression, gestural). This conditioning was conducted from the 10th to the 14th meeting. This effort proved to be very helpful to the students' self-confidence, thus further improving their communication skills (Observation. March-May 2018). This method also develops active listening and helps share skills. As one student expressed, "We cannot expect to grasp the meaning of the world without listening to and sharing insights with the people around us."

In an after-class debriefing, all five students who were given a chance to give their feedback responded that they were able to speak up because they have the in-depth information while discussing within the expert group. The students believed that by applying the jigsaw method and mind mapping to prepare their presentation, they could at least have the confidence to share the knowledge. By having the information, they 
gain more confidence in contributing to the discussion because they can share more about the content with the original group. Each person inside the original group has their particular information to be shared, and the lecturer did not interrupt the discussion. As a result, the students were eager to discuss more about the content (Class debriefing, June 7, 2018). The implementation of the Jigsaw method was combined with activities that could stimulate the students to speak up their mind. Even in every class meeting the lecturer and the students held a reflection regarding the students' performance during the presentation, which is followed by suggestions for a more communicative discussion, both as a speaker and as a listener.

An effective discussion needs to have an interactive communicator. Effective communicators are focused on their purpose, consider the audience, try to engage the audience to listen, see, and care about what the communicator said (Fred Garcia, 2012). Communication is a process of building a shared understanding. In this case, what must be done by the communicator is through verbal behavior, vocal behavior, and physical behavior (Sutiyatno, 2018). Good communication relations are reflected by giving physical signs of being friendly, relaxed and open between the speakers and the listeners. A decent communicator should be able to use appropriate words for different persons, and in various situations, so the listeners would feel that the communicator 'speaks their language.'

Also, the findings are parallel with Gillies and Ashman (2008) who stated that the cooperative learning method could enhance students' verbal communication. Those interpersonal skills are (a) actively listening to each other during group discussions, (b) considering others' perspective on issues, (c) expressing ideas freely without fear of comment, (d) being responsible for their behavior, and (e) constructively criticize the ideas presented. Furthermore, through cooperative learning, students can learn more when they are given opportunities to discuss with their peers. The students were able to answer $75 \%-100 \%$ of the total questions given at the class debriefing. This finding indicates that they had gained more understanding of the assigned topics by conducting an independent discussion among their peers.

Increased understanding of pedagogical content knowledge and verbal communication skills of these prospective teacher students occurred because they have the opportunities to practice both as speakers and listeners by conducting the Jigsaw method. The students who were involved in Jigsaw Type Cooperative Learning method acknowledged that they have a more positive attitude toward the learning process. Aside from that, the fundamental advantages of Jigsaw success in improving students' verbal communication skills are strongly supported by activities that challenge them to practice in communicating.

In line with this, the verbal skills should be taught and internalized, practiced not once, but intensively with increasing difficulties of the tasks assigned. Training the students is equally important, they have to do much reflection, so it becomes automatic, and students can develop the habit of critical evaluation, high motivation, and performance (Hoerr, 2010). Therefore, the implementation of Jigsaw-Type cooperative learning method was able to help prospective teachers in understanding the subject material 
(pedagogical content knowledge) well and at the same time to improve verbal communication skills.

\section{CONCLUSION}

The findings of the study have the potential to impact educational research and practice in several ways. Firstly, the application of jigsaw-type cooperative learning method in the learning process has beneficial roles to assist prospective teacher students in achieving a proper understanding of the pedagogical content knowledge and at the same time improving their verbal communication skill. Secondly, the method succeeds to challenge every student in constructing the knowledge in the "expert" groups; then the students individually must convey back their understanding of the original group in a more informative manner. Students were accountable for determining the essential points in the expert group and were able to articulate them to their peers appropriately. In other words, the Jigsaw technique can be considered as one of the most effective ways to encourage students' to participate actively in learning and to enhance their communication skills.

\section{REFERENCES}

Aronson, E. (2002). Building Empathy, Compassion, and Achievement in the Jigsaw Classroom. Improving Academic Achievement: Impact of Psychological Factors on Education, 209-225. https://doi.org/10.1016/B978-012064455-1/50013-0

Aronson, E., \& Bridgeman, D. (1979). Jigsaw Groups and the Desegregated Classroom: In Pursuit of Common Goals. Personality and Social Psychology Bulletin, 5(4), 438446. https://doi.org/10.1177/014616727900500405

Avalos, B. (2013). Teacher professional development in teaching and teacher education from 2000-2010. Advances in Research on Teaching. https://doi.org/10.1108/S14793687(2013)0000019012

Aydin, A., \& Biyikli, F. (2017). The Effect of Jigsaw Technique on the Students' Laboratory Material Recognition and Usage Skills in General Physics Laboratory-I Course. Universal Journal of Educational Research, 5(7), 1073-1082. https://doi.org/10.13189/ujer.2017.050701

Azmin, N. H. (2015). Effect of the Jigsaw-Based Cooperative Learning Method on Student Performance in the General Certificate of Education Advanced-Level Psychology: An Exploratory Brunei Case Study. International Education Studies, 9(1), 91. https://doi.org/10.5539/ies.v9n1p91

Benton, R. (2016). Put Students in Charge: A Variation on the Jigsaw Discussion. College Teaching. https://doi.org/10.1080/87567555.2015.1069725

Bullock Michael, S. (2011). Inside Teacher Education: Challenging Prior Views of Teaching and Learning. Sense Publishers.

Cardozo, L. T., Miranda, A. S., Moura, M. J. C. S., \& Marcondes, F. K. (2016). Effect of a puzzle on the process of students' learning about cardiac physiology. Advances in 
Physiology Education, 40(3), 425-431. https://doi.org/10.1152/advan.00043.2016

Carroll, D. W. (1986). Use of the Jigsaw Technique in Laboratory and Discussion Classes. Teaching of Psychology, 13(4), 208-210. https://doi.org/10.1207/s15328023top1304_9

Cohan, A., \& Honigsfeld, A. (2011). Breaking the Mold of Preservice and Inservice Teacher Education: Innovative and Successful Practices for the Twenty-First Century. New York: Rowman \& Littlefield Education.

Creswell, J. W. (2013). Research Design: Qualitative, Quantitative, and Mixed Methods Approaches. Research design Qualitative quantitative and mixed methods approaches. https://doi.org/10.1007/s13398-014-0173-7.2

Dalgleish, T., Williams, J. M. G. ., Golden, A.-M. J., Perkins, N., Barrett, L. F., Barnard, P. J., ... Watkins, E. (2007). Teaching Cooperative Learning. Journal of Experimental Psychology: General (Vol. 136).

Deci, E., J. Schwartz, A., Sheinman, L., \& Ryan, R. (1981). An instrument to assess adults' orientations toward control versus autonomy with children: Reflections on intrinsic motivation and perceived competence. Journal of Educational Psychology, 73, 642-650. https://doi.org/10.1037/0022-0663.73.5.642

Departemen Pendidikan dan Kebudayaan. Undang-Undang Nomor 14 Tahun 2005 tentang Guru dan Dosen (2005). Indonesia.

Effendi, R., \& Sukmayadi, V. (2016). Communication apprehension levels of tourism and social sciences students. In Heritage, Culture and Society: Research agenda and best practices in the hospitality and tourism industry - Proceedings of the 3rd International Hospitality and Tourism Conference, IHTC 2016 and 2nd International Seminar on Tourism, ISOT 2016.

Eilks, I. (2005). Experiences and Reflections about Teaching Atomic Structure in a Jigsaw Classroom in Lower Secondary School Chemistry Lessons. Journal of Chemical Education, 82(2), 313. https://doi.org/10.1021/ed082p313

Fred Garcia, H. (2012). The Power of Communication. New Jersey: Pearson Education.

Frymier, A. B., \& Houser, M. L. (2000). The teacher-student relationship as an interpersonal relationship. Communication Education. https://doi.org/10.1080/03634520009379209

Fujishin, R. (2009). Creating Communication: Exploring Your Fundamental Communication Skills. National statement on the use of calculators for mathematics in Australian schools. Maryland: Rowman \& Littlefield Publishers, Inc.

Gillies, R. M., Ashman, A. F., \& Terwel, J. (2008). The Teacher's Role in Implementing Cooperative Learning in the Classroom. (P. Dillenbourg, Ed.). Springer Science.

Gore, J. M., Griffiths, T., \& Ladwig, J. G. (2004). Towards better teaching: Productive pedagogy as a framework for teacher education. Teaching and Teacher Education. 
https://doi.org/10.1016/j.tate.2004.02.010

Grace, D. M., \& Gilsdorf, J. W. (2004). Classroom strategies for improving students' oral communication skills. Journal of Accounting Education. https://doi.org/10.1016/j.jaccedu.2004.06.001

Hoerr, T. R. (2010). Celebrating Every Learner: Activities and Strategis for Creating a Multiple Inteligences Classroom. Jossey-Bass.

Ibrahim, A. S. (2013). Approaches to supervision of student teachers in one UAE teacher education program. Teaching and Teacher Education. https://doi.org/10.1016/j.tate.2013.04.002

Jolliffe, C. W. (2012). Cooperative Learning in the Classroom : Putting it into Practice Putting Cooperative Learning into Practice Chapter 6: Putting Cooperative Learning into Practice Incorporating Cooperative Learning into Lessons. https://doi.org/10.4135/9781446213971

Kagan, S., \& Kagan, M. (2009). Kagan Cooperative Learning. Co-operative Learning.

Khan, A., Khan, S., Zia-Ul-Islam, S., \& Khan, M. (2017). Communication Skills of a Teacher and Its Role in the Development of the Students' Academic Success. Journal of Education and Practice, 8(1), 18-21. Retrieved from http://ezproxy.lib.uconn.edu/login?url=https://search.ebscohost.com/login.aspx?direct=t rue $\& \mathrm{db}=$ eric $\& \mathrm{AN}=\mathrm{EJ} 1131770 \&$ site $=$ ehost-live

Koprovwsa, J. (2014). Communication and Interpersonal skills in social work, 188. https://doi.org/10.1097/MOU.0b013e32834b1317

Kouwenhoven, H., Ernestus, M., \& van Mulken, M. (2016). Communication strategy used by Spanish speakers of English in formal and informal speech. International Journal of Bilingualism, 22(3), 285-304. https://doi.org/10.1177/1367006916672946

Kukner, J. M., \& Orr, A. M. (2015). Inquiring into Pre-service Content Area Teachers' Development of Literacy Practices and Pedagogical Content Knowledge. Australian Journal of Teacher Education. https://doi.org/10.14221/ajte.2015v40n5.3

McMillan, J. H., \& Schumacher, S. (2001). Research in education: A conceptual introduction. New York: Longman.

Moore-Russo, D., Viglietti, J. M., Chiu, M. M., \& Bateman, S. M. (2013). Teachers' spatial literacy as visualization, reasoning, and communication. Teaching and Teacher Education. https://doi.org/10.1016/j.tate.2012.08.012

Ngang, T. K., Hashim, N. H., \& Yunus, H. M. (2015). Novice Teacher Perceptions of the Soft Skills Needed in Today's Workplace. Procedia - Social and Behavioral Sciences. https://doi.org/10.1016/j.sbspro.2015.02.338

Ozkan, H., Dalli, M., Bingol, E., Metin, S. C., \& Yarali, D. (2014). Examining the Relationship between the Communication Skills and Self-efficacy Levels of Physical Education Teacher Candidates. Procedia - Social and Behavioral Sciences. 
https://doi.org/10.1016/j.sbspro.2014.09.228

Ramdhani, N., Ancok, D., Swasono, Y., \& Suryanto, P. (2012). Teacher Quality Improvement Program: Empowering Teachers to Increasing a Quality of Indonesian's Education. Procedia - Social and Behavioral Sciences. https://doi.org/10.1016/j.sbspro.2012.12.134

Rots, I., Aelterman, A., Devos, G., \& Vlerick, P. (2010). Teacher education and the choice to enter the teaching profession: A prospective study. Teaching and Teacher Education. https://doi.org/10.1016/j.tate.2010.06.013

Slavin, R. E. (1980). Cooperative learning in teams: State of the art. Educational Psychologist, 15(2), 93-111. https://doi.org/10.1080/00461528009529219

Soares, F. (2015). The Relationship between Teachers and Students in the Classroom: Communicative Language Teaching Approach and Cooperative Learning Strategy to Improve Learning.

Sutiyatno, S. (2018). The Effect of Teacher's Verbal Communication and Non-verbal Communication on Students' English Achievement. Journal of Language Teaching and Research, 9(2), 430-437. https://doi.org/http://dx.doi.org/10.17507/jltr.0902.28

Syarifuddin, A. (2011). Model Pembelajaran Cooperative Learning Tipe Jigsaw Dalam Pembelajaran. Ta'dib. IAIN Raden Fatah Palembang, XVI(2), 209-226. Retrieved from http://jurnal.radenfatah.ac.id/index.php/tadib/article/download/61/56

Wiens, P. D., Hessberg, K., LoCasale-Crouch, J., \& DeCoster, J. (2013). Using a standardized video-based assessment in a university teacher education program to examine preservice teachers knowledge related to effective teaching. Teaching and Teacher Education. https://doi.org/10.1016/j.tate.2013.01.010 